\title{
O narrador em Do outro mundo: articulação entre a memória e a escrita na novela de Ana Maria Machado
}

\author{
Luciete de Cássia Souza Lima Bastos
}

Mestre em Letras: Teoria Literária - UFMG e docente na UNEB

\begin{abstract}
RESUMO
Este ensaio discute a memória na obra de Ana Maria Machado com ênfase na novela Do outro mundo (2002), produção infanto-juvenil, pelo intercurso do narrador, procurando articular a memória das experiências vividas pela autora e a (re)construção, pela escrita, das sensações/impressões do vivido, atualizadas pelo sujeito que narra; plano em que se interpenetram o autor e o narrador.
\end{abstract}

\section{PALAVRAS-CHAVE}

Narrador, memória, imaginação, Ana Maria Machado

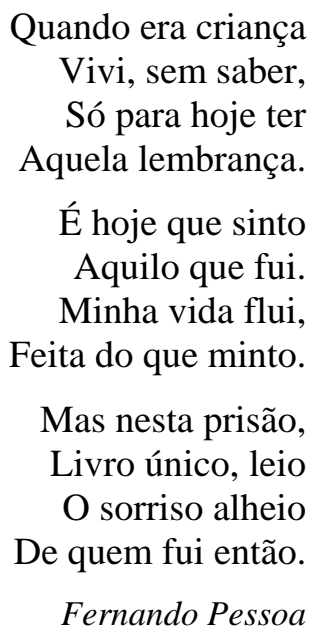

Este texto constitui uma reflexão sobre a escrita de Ana Maria Machado, considerando os pontos que promovem a leitura da novela Do outro mundo (2002) como uma obra de ficção na qual Ana Maria revisita a si mesma como autora. O passado da escritora transforma-se em matéria de sua obra, como meio de fixar a memória, notadamente de 
natureza efêmera, uma matéria única que, pela escrita, se transforma em arte. Ela manipula, ${ }^{1}$ de forma engenhosa, detalhes que adquirem o status de fato, um permanente diálogo entre as imagens da infância resgatadas pelas lembranças e uma imaginação bastante fértil, que a mantém em constante produção. Ana Maria não menospreza a capacidade de apreensão de seus jovens leitores, usa, com algumas restrições, construções mais elaboradas. Os eventos da vida particular são manipulados por um conjunto de processos linguístico-expressivos, dentre eles a mise en abyme, ${ }^{2}$ a analepse ou flashback, ${ }^{3}$ a desliteralização da linguagem, a intertextualidade e a metalinguagem, que revelam um alcance estético para além da simples representação.

Ana Maria Machado torna possível o diálogo entre o que poderia ter sido, resgatado pela memória e interpretado pelo sujeito que escreve, e o que é (re)construído pelo narrador que no presente relata. Procuro focar a não linearidade da trama, cujos enlaces espaçotemporais se abrem à multiplicidade, articulando passado (memória da infância), presente (recriado) e futuro (imaginado), em arranjos que caminham pela sobreposição de planos narrativos. Para esse percurso em que o pretérito é (re)criado no presente narrativo, via autor que o atualiza na voz do narrador, procurei sustentação na teoria sobre o escritor criativo

${ }^{1}$ Emprego o verbo "manipular" por falta de melhor termo que traduza a ideia consciente do jogo entre elementos, com o objetivo de dar caução de fato ao imaginado.

2 Segundo conceituação de Annabela Rita (2005), a mise en abyme consiste num processo de reflexividade literária, de duplicação especular. Tal autorrepresentação pode ser total ou parcial, mas também pode ser clara ou simbólica, indireta. Numa modalidade mais simples, mantém-se no nível do enunciado: uma narrativa vê-se sinteticamente representada num determinado ponto do seu curso. Noutra modalidade, um pouco mais complexa, o nível de enunciação seria projetado no interior dessa representação: a instância enunciadora se configura no texto em pleno ato enunciatório. A modalidade mais complexa abrange ambos os níveis, o do enunciado e o da enunciação, fenômeno que evoca, no texto, quer as suas estruturas, quer a instância narrativa em processo. A mise en abyme favorece, assim, um fenômeno de encaixe na sintaxe narrativa, ou seja, de inscrição de uma micronarrativa dentro da outra principal, a qual, normalmente, arrasta consigo o confronto entre níveis narrativos. Considero pertinente informar, mesmo que sinteticamente, o seu aparecimento no contexto da obra do escritor e ensaísta francês André Gide, que utilizou dessa estrutura para colocar em xeque o próprio conceito de Ficção e de Real em Os moedeiros falsos, romance de 1925.

${ }^{3}$ Na narrativa literária ou cinematográfica, diz-se de todo fato que, pertencendo ao passado, é trazido para o presente da história relatada. Carlos Ceia [s.d.] conceitua analepse como um fenômeno de anacronia, também conhecido como flashback, cutback ou switchback. O flashback joga com a estrutura narrativa; pode corresponder à produção de uma presença anamnésica dos acontecimentos atuais com outros ocorridos no passado, gerando uma espécie de profundidade afetiva. É, em geral, utilizado para provocar efeitos de suspense, guardando em reserva a solução do enigma narrativo até o desfecho da ação. Tanto as unidades relacionais como as unidades representantes distinguemse das unidades referenciais e dêiticas. Enquanto as unidades relacionais e as unidades representantes remetem para outras unidades presentes no texto, as unidades referenciais remetem para objetos do mundo, real ou fictício, e as unidades dícticas remetem para as instâncias enunciativas. 
de Sigmund Freud, ${ }^{4}$ na teoria sobre o fictício e o imaginário de Wolfgang Iser ${ }^{5}$ e na teoria da narrativa de Oscar Tacca, ${ }^{6}$ que foram de grande valia para a leitura analítica que me propus desenvolver.

A narrativa é pautada por um tempo que navega entre o passado e o futuro, sustentado pelo presente da escrita, um tempo interior, marcado pela interrupção que se engendra a partir duma memória, duma percepção, duma imaginação descontínua. Através da memória e da imaginação, a autora consegue articular experiências vividas e imaginadas e aproximar sua vivência de adulto do universo de expectativas do jovem leitor. Ela apresenta uma história imaginária como se fosse real, constituída por uma pluralidade de personagens, cujos episódios de vida se entrelaçam num tempo e num espaço determinados pela própria narrativa. Tais marcas temporais, típicas de uma narrativa guiada por idas e vindas na memória, não deixam dúvidas quanto às épocas em que ocorreram as ações e podem ser recuperadas através das flexões verbais, advérbios, estruturas e/ou semântica das frases.

A história Do outro mundo, que se desenrola desde os planos de transformar uma antiga fazenda de café em pousada até a sua instalação, é moldura para uma segunda história, estabelecendo, destarte, o argumento para as ações posteriores: o contato de Mariano, narrador da primeira história, com o espectro de Rosário, e consequente narrativa da história de vida e de morte da escravinha. Enquanto a reforma da velha fazenda colonial não é concluída e o anexo da pousada não é liberado para os hóspedes, a antiga instalação da senzala é utilizada para o deleite de Mariano e seus amigos nos fins de semana. É nesse ambiente, envolto em mistérios, que tudo acontece. Ruídos estranhos e choro sufocado por gemidos perturbam o sono das crianças; a causadora dos ruídos assustadores no meio da noite é o fantasma de uma garotinha negra.

A pousada constitui ambiente propício ao evento sobrenatural que se desencadeia a partir dali, principalmente por se tratar de um local cuja história remete ao século 19. Elementos do universo empírico são convocados para dar maior verossimilhança ao que está sendo narrado, ora o enredo se volta para o ambiente característico daquela época, como, por exemplo, nestas passagens: “(...) uma tal princesa tinha assinado uma lei e ninguém mais podia ter escravo (...)”7 e (...) “O fim da escravidão tinha sido em 1888”, 8 ora é visitado o

\footnotetext{
${ }^{4}$ FREUD. Escritores criativos e devaneio.

${ }^{5}$ ISER. O fictício e o imaginário: perspectivas de uma antropologia literária.

${ }^{6}$ TACCA. As vozes do Romance.

${ }^{7}$ MACHADO. Do outro mundo, p. 85-86.
} 
cotidiano citadino do século 20: “(...) eles não podiam usar o computador e ficar navegando na rede(...).”9 $\mathrm{Na}$ propriedade, é possível encontrar vários objetos que lembram a época imperial, a exemplo do castiçal de Iaiá, que se torna peça-chave que propicia a comunicação entre os "mundos”, o das crianças e o do espectro, elo que liga os dois tempos da narrativa: passado e presente. Num e noutro caso, embora possível a identificação de fatos históricos, trata-se de uma obra ficcional. Não se pode confundir a realidade com aquilo que é contado, a realidade se (re)escreve e se (re)constrói pelas possibilidades da invenção; se há uma permuta entre o real e o imaginário, há muito mais espaço para a fantasia. Iser ${ }^{10}$ afirma que “o fictício não é idêntico à obra literária, mas a possibilita”.

O encontro entre passado e presente é a marca mais forte em Do outro mundo. Mariano subverte a linearidade em movimentos retrospectivos, para relatar, com mais detalhes, acontecimentos que julga serem essenciais para a compreensão da ação presente. $\mathrm{O}$ “retorno” de Rosário se liga a dois desejos: o primeiro, saber sobre o paradeiro de seu irmão Amaro; o segundo, escrever e divulgar a sua história, para que não seja esquecida e eventos semelhantes nunca voltem a ocorrer. Aí está o motivo que justifica a escrita do livro, cuja narração ficou sob a incumbência de Mariano. As peças do quebra-cabeça vão construindo sentido, o mistério vai se desvelando e revelando que Amaro é um ancestral de Léo e Elisa, companheiros de Mariano nessa aventura. Com a solução do mistério, a história de Rosário chega ao fim. A história de Mariano continua, plena de vida, porque ele narra.

Embora o foco narrativo em primeira pessoa determine a história, o narrador não esconde a sua condição de transcritor, a fuga da autoria se justifica pela alegação de que apenas transcreve o relato de Rosário e se intensifica ao admitir a coparticipação dos amigos na escrita e organização gráfica do texto. No último capítulo da história principal, Mariano dá visibilidade para a preocupação comum a todos os escritores: a forma do texto, todo o processo de construção, desde a sua elaboração escrita até a ilustração é partilhada, o narrador chega a afirmar que os amigos (re)estruturaram ou praticamente (re)escreveram o livro: “Eles é que acabaram dando as sugestões e escolhendo tudo. Até o nome do livro.”11 Segundo Oscar Tacca, ${ }^{12}$ “o autor flutua, como vemos, entre o ser e não ser, ou, melhor dizendo, entre ser e aparecer: desde a tímida presença até a ausência deliberada.” Nesse sentido, o recurso de

\footnotetext{
${ }^{8}$ MACHADO. Do outro mundo, p. 91.

${ }^{9}$ MACHADO. Do outro mundo, p. 56.

${ }^{10}$ ISER. O fictício e o imaginário: perspectivas de uma antropologia literária, p. 209.

${ }^{11}$ MACHADO. Do outro mundo, p. 116.

${ }^{12}$ TACCA. As vozes do romance, p. 45.
} 
autor-transcritor tende para a verossimilhança; é necessário ressaltar, entretanto, que em literatura a verossimilhança é uma convenção, pois não provém de uma dicotômica relação de verdade/mentira entre o discurso e seu referente, mas entre o discurso e aquilo que os leitores aceitam como verdadeiro por convenção.

À medida que Mariano escreve, vai dando caução de “fato” à narração, via provas como o castiçal, à negação de autoria e à construção em abismo, transformando em história a sua lembrança e transcrevendo o relato das lembranças de Rosário. A novela Do outro mundo, muito mais do que uma reflexão temática sobre a escravidão, constitui uma imagem do processo de evolução intelectual da autora através das reflexões e questionamentos das personagens sobre o ato de escrever e sobre a própria linguagem. É condição sine qua non, nesse jogo, o fingimento pactuado: de um lado o que é narrado dá aparência de verdade, passa confiabilidade; de outro, há o assentimento mais ou menos consciente do artifício da fantasia. O que conta o romancista na voz do narrador não se questiona, aceita-se apenas, porque o que diz o relato é “verificável”, o leitor não pode negar, nem duvidar, por isso se fala em caráter mimético do discurso narrativo, a opinião comum do leitor se entrega às leis do jogo, sem cuja aceitação incondicional em se submeter ao engodo, o romance deixa de existir. É com base no fingimento anunciado e consentido que o romance se realiza.

Do outro mundo é uma obra que condensa várias cápsulas espaciotemporais num único continuum, que nos leva a experimentar o prazer de navegar nos vãos recuados e aproximativos entre os tempos, até o ilimitado que o prazer estético propicia. É a memória, com seus volteios e desvios característicos, que orienta o desenrolar da história em Do outro Mundo, presente narrativo e passado (re)lembrado acontecem a um só e mesmo tempo, o que me permite transitar entre os limites permeáveis do ficcional e da história convencional. Embora a novela apresente uma estrutura abismal, aparentemente confusa, o tempo pode ser recuperado indiretamente pelo leitor, juntando-se as marcações temporais espalhadas ao longo do texto. Essa forma de composição possibilita a captação simultânea dos elementos que entram em atividade na narração, sua inter-relação e o modo de seu funcionamento, possibilitando jogos que permitem alternar os momentos de realidade da vida com os da realidade da obra.

Essa técnica denuncia uma dimensão reflexiva do discurso, uma consciência estética ativa que evidencia a ficção pela redundância textual e reforça a coerência e a previsibilidade ficcionais. Uma metanarrativa que atrai ainda mais o leitor para o jogo da criação e que se torna providencial no caso da literatura destinada aos jovens leitores. Essa prática é recorrente na obra de Ana Maria Machado, pois essa estrutura permite que os próprios leitores, 
percebendo com mais nitidez a natureza do ficcional no jogo de relações entre as personagens da obra central e as das narrativas secundárias, gozem, de forma mais consciente, de tal experiência estética. Todas as marcas temporais estão ligadas a um tempo mítico ${ }^{13}$ que se movimenta no passado próximo (ontem) ou longínquo (fim da escravidão) e futuro como possibilidade de transformação. O presente, ponto de referência das demais temporalidades, é um tempo vital para a narrativa, pois vai se construindo como desafio, um tempo aberto para o novo.

Não é difícil perceber uma projeção da infância de Ana Maria na sua literatura; a criança curiosa e questionadora emerge na autora, que, por outro caminho, busca respostas para as inquietantes perguntas sobre o ser e estar no mundo. A concepção que Ana Maria tem da infância, assim como a forma com que ela traz as experiências da infância (re)criadas para a sua obra, é relevante para a percepção da literatura infantil e juvenil como arte. Quer por meio de suas vivências, quer por meio das leituras realizadas, Ana conquistou um acervo cultural que lhe permite produzir ficção e textos ensaísticos de qualidade. O projeto teórico e o projeto estético de Ana Maria levam a pensar na busca da identidade da própria literatura infantil, quer quando nos ensaios defende os bons textos modernos e/ou difunde a leitura dos clássicos universais, quer na ficção, quando aborda temáticas sérias como o questionamento do poder, as relações sociais, a liberdade e a escravidão, a repressão e o exílio, a busca pelo crescimento pessoal e a construção do eu, a condição feminina, a diversidade cultural, ou ainda, pela frequência insistente do tema leitura/escrita; temas que, não raras vezes, se emaranham, como ocorre na novela em estudo. A escolha dos temas, os múltiplos recursos linguístico-expressivos, a versatilidade/arejamento da linguagem literária e a humanização do leitor demonstram o profundo respeito de Ana Maria pela criança e pelo jovem. A autora concebe a literatura como sinônimo da fusão entre prazer e conhecimento, por isso continua produzindo, independentemente da classificação etária que se possa aferir às suas obras.

Com fulcro no texto de Freud Escritores criativos e devaneios (1976), afirmo que essa experiência na infância serve ao propósito criativo em razão da afinidade inventiva entre a

\footnotetext{
${ }^{13}$ Jung refere-se a um tempo mítico, ligado à maneira de pensar dos gregos, que se referiam ao tempo, chronos e kairós, como demarcadores do discurso. O primeiro, o tempo cronológico, é uma sequência de instantes homogêneos, que se sucedem ininterruptamente; o segundo, kairótico, não é um tempo homogêneo, é des-continuidade, marcado pela diferença e pela ruptura. Este tempo corta a sucessão temporal, marcando uma significativa diferença entre o que vem antes e o que vem depois. Aqueles que vivenciam o tempo kairótico não podem determinar antecipadamente o tempo certo para então agir, aguardam um futuro desconhecido e se preparam para responder; a resposta é vital, já que neste tempo o presente não está predeterminado e plenamente formado; antes, o presente é oportunidade e desafio: é um tempo aberto para o novo. (JUNG. Os arquétipos e o inconsciente coletivo, p. 35.)
} 
fantasia da menina e a criação da escritora, que busca, pela memória afetiva, resgatar momentos em que a brincadeira, a fantasia e o jogo eram elementos fundamentais à vida da criança Ana, estabelecendo, dessa forma, um diálogo com a mulher que hoje busca, nessas experiências rememoradas, elementos necessários à criação artística. Nas palavras de Freud: “Uma poderosa experiência no presente desperta no escritor criativo uma lembrança de uma experiência anterior (geralmente sua infância), da qual se origina então um desejo que encontra realização na obra criativa. ${ }^{14}$ Do mesmo modo como brincar é uma necessidade essencial na infância, por permitir a criação de um mundo imaginário a partir do cotidiano, as fantasias, quando bem direcionadas, passam a fazer parte do universo criativo do escritor, multifacetadas nos heróis que finge ser.Tanto a criança como o artista inventam um universo próprio onde desejam morar por algum tempo, mas ambos têm consciência do que é a realidade e do que é a fantasia; o universo imaginário é para a criança tão real como é real o mundo da ficção para quem cria.

Ao se referir à sua produção, Ana Maria afirma que escreve num estilo próprio, em que tenta conciliar memória e imaginação. Nas palavras da autora: "Memória do que vi e vivi, muitas vezes na infância. Imaginação que nunca foi tão soberana como em meu tempo de menina. Daí o papel fundamental do universo infantil na minha relação com a literatura." ${ }^{15}$ As experiências da infância são importantes fontes para a invenção artística, ímpar em cada escritor, de onde advém a singularidade distintiva do estilo. É com esse olhar inaugural e de encantamento, próprio à infância, que Ana Maria olha o mundo, um universo facilmente identificado em sua obra através das personagens e do mundo descrito nas narrativas que constantemente fazem referências às pessoas biografáveis, alusão a lugares e ambientes comuns à infância, matéria única e singular que Ana transforma em literatura, como a fazenda de café que virou pousada tornou-se ambiente propício para o sobrenatural.

Os acontecimentos vivenciados pela autora se apresentam de forma desordenada, a matéria é transformada no ato da criação pelo processo a que Iser denomina de "atos de fingir”, atos entre si intercambiáveis no espaço do jogo. Segundo o crítico,

o ato de seleção abre um espaço de jogo entre os campos referenciais e sua deformação no texto; o ato de combinação abre outro espaço de jogo entre a interação recíproca dos segmentos textuais e o ato do como se abre um espaço de jogo entre um mundo empírico e sua metaforização. ${ }^{16}$

\footnotetext{
${ }^{14}$ FREUD. Escritores criativos e devaneio, p. 156.

${ }^{15}$ MACHADO. Texturas: sobre leituras e escritos, p. 102. (grifos nossos)

${ }^{16}$ ISER. O fictício e o imaginário: perspectivas de uma antropologia literária, p. 265. (grifos nossos)
} 
Aparentemente simples e sem a adoção de regras prévias, Ana escolhe no universo empírico ou resgata das experiências o que pretende utilizar em sua escrita. Não se trata de uma cópia; a seleção operada, dentre outras disponíveis, não se repete única e/ou passivamente no texto, dobra-se à força do imaginário; nele, a realidade é transformada em signo de outra coisa. O que se dá, a partir de então, é um jogo que possibilita, através da mimese verbal, a encenação de uma realidade que, imediatamente, se faz imaginária e, portanto, se inscreve no mundo do fingimento. Nesse deslizamento, é possível organizar formas e configurações para experiências incognoscíveis no plano cotidiano, como aquela processada na novela Do outro mundo: ao se dar voz a um narrador morto, fantasma, portanto, cria-se um espaço para uma alteridade imaginária. Consciente desse processo, Ana se multiplica nos inúmeros personagens que inventa.

Abordei até aqui sobre a consciência subjetiva da autora, que, no processo de criação literária, ativa intencionalmente o imaginário. Em várias passagens da novela, também Mariano aciona o imaginário, levando-me a pensar que o narrador, à semelhança do que ocorre com outros autores, também se dissimula na segunda história, finge que finge tratar-se de outro narrador, conferindo, desta forma, maior verossimilhança à narrativa. A narrativa é conduzida por um narrador onipresente, que se coloca sempre onde for mais conveniente aos objetivos da narrativa. Desse modo, Mariano vai construindo seus conhecimentos, paulatinamente, auxiliado pelos pontos de vista secundários dos demais personagens, de maneira a incorporar as informações para tirar delas o melhor proveito.

A dificuldade com a escrita persegue o narrador do princípio ao fim do texto. Mariano afirma que, se fosse ficcionista, talvez fosse mais fácil inventar, deixar a narrativa mais lenta, mas não sabe fingir: "Se eu estivesse mais acostumado a escrever, talvez soubesse inventar (...) acho que ia aumentar muito o suspense (...)”; ${ }^{17}$ da afirmação de Mariano é possível depreender que o que ele narra é “verdadeiro”, posto que não consegue fingir. As afirmações ficcionais são verdadeiras dentro da própria estrutura da obra ficcional e, por conseguinte, o que o narrador diz ser verdade, é inquestionável. Iser ${ }^{18}$ escreve que os elementos que existem na vida real também permeiam a literatura; nela, entretanto, a articulação desses elementos é organizada, mesmo não podendo ser fundamentada, um elemento serve de contexto para o outro. É a estrutura que possibilita a lógica narrativa e dá um aval de verossimilhança à ficção.

\footnotetext{
${ }^{17}$ MACHADO. Do outro mundo, p. 32.

${ }^{18}$ ISER. O fictício e o imaginário: perspectivas de uma antropologia literária, p. 209-302.
} 
A função do narrador permite postular a existência de um destinatário, recurso bastante usado por Ana Maria Machado, como nessa novela, em que o seu narrador estabelece um diálogo com um narratário, um personagem de ficção, o tipo ideal de leitor que o narrador, como produtor do discurso, tem em mente e que se revela segundo as marcas textuais que se efetivam ao longo do texto: “Você me desculpe. (...) Para começar, não sei começar. (...) Mas isso só vamos ver depois (...) Mas nem sei se é para um amigo só ou para uma porção de gente. Se peço desculpas a você ou a vocês. Seja como for, peço (...)." ${ }^{19}$ Essa categoria se instala logo na primeira linha, pela voz do narrador, que o convida à cumplicidade, e nessa função de “ouvinte atento” acompanha o narrado do princípio ao fim do texto; embora portador de uma presença não manifesta por voz, a sua existência é inquestionável e exerce uma função importante: a de motivar o desenrolar da narração. Com efeito, o narratário tem também a função de dinamizar ou conter a narrativa, processo dramático interiorizado no narrador; o narratário é, por conseguinte, “o simétrico do narrador”. Com as palavras de Tacca “há uma modulação da voz do narrador (...) motivada pelo destinatário ou receptor. (...) as formas do discurso narrativo estão em função do destinatário a quem o destinador se dirige (...) ${ }^{20}$ Essas convocações demonstram a importância do ouvinte para o relato, como se ao narratário coubesse o papel de testemunhar, validar a história.

A literatura de Ana se projeta em direção à ocupação de um entre-lugar, a terceira margem anunciada na poética de Guimarães Rosa, um espaço intersticial em que a ficção se realiza; nela, o cotidiano é invadido pelo inusitado, um universo repleto de magia e de verdade, em que o imaginário e o realismo dialogam. Nesse espaço da novela, grande relevância é dada à escrita como elemento fundamental para a constituição do narradorescritor, um percurso de autoconhecimento e de busca de identidade. A experiência de vida do narrador Mariano contribuiu para compreender as relações entre realidade e imaginação e a importância que essas relações representam para o resgate das relações indivíduo/meio, como estabelecimento de um sentido maior para a percepção do sujeito no mundo, neste caso, as crianças leitoras de Ana Maria.

A novela Do outro mundo é parte de um projeto maior que Ana refaz a cada livro, parte de uma labiríntica cadeia da obra total. Cada obra se assume como itinerário, cujo horizonte é a totalidade que se cumpre naquilo que ainda não foi dito, pois está por ser inventado. Há nela um ímpeto, uma força consciente que a move e a conduz ao início e ao

\footnotetext{
${ }^{19}$ MACHADO. Do outro mundo, p. 11-12. (grifos nossos)

${ }^{20}$ TACCA. As vozes do romance
} 
centro de toda a sua obra, dando-lhe uma unidade de lugar que é a sua paixão pela língua portuguesa, que se realiza na sua escrita, seja ficcional, seja ensaística. Trata-se de uma escrita de múltiplos significados, que se gera a si própria, abrindo infinitos caminhos que se harmonizam num todo. É por isso que a escrita de seus textos precisa ser entendida como um inventar contínuo e não como simples representação. A garota que vive no interior de Ana, íntegra e vibrante, reitera a dimensão poética da alma da artista, propulsora do jogo lúdico de sua criação. Ana é uma boa autora de livros para jovens leitores, porque escreve para a criança que foi; ao ver o mundo sob a ótica poética, a autora não carece de fabricar artifícios para um discurso que sensibilize a criança, porque a linguagem e a forma de ver o mundo brotam, naturalmente, da criança que a habita e que com a Ana adulta se reconcilia na escrita.

Segundo minha leitura, sua obra é perpassada pela tentativa de não perder o fio da meada, qualquer que seja o aspecto considerado: a escolha do narrador, o tipo de discurso, as informações que veicula, os recursos estético-expressivos utilizados, a escolha das obras com as quais mantém diálogo, a introdução do inusitado e da magia, toda escolha se processa sob o olhar atento da escritora. É a magia no universo do cotidiano que a encanta e a língua em suas possibilidades que a instiga. Consciente da natureza mutável do signo linguístico, a autora transita livremente entre o tradicional a as transgressões possíveis, em busca da inovação estética, o que resulta numa trama híbrida de linguagens. A leitura de suas obras revela alguém que conhece a cultura de seu povo, movimentando-se naturalmente entre a cultura popular e a erudita. Ao colocar o seu leitor diante de uma multiplicidade de sentimentos e de pontos de vista, Ana cria com ele um jogo de identificações e de estranhamentos, o que provoca a contínua interação entre as expectativas modificadas e as memórias transformadas.

Uma última palavra sobre o narrador inspirada em Oscar Tacca: como um mestre de mil e uma máscaras, o narrador esquivou-se pela narrativa, afastando-se a cada tentativa de aproximação de análise; quanto mais dele pensei conhecer, quanto mais dados acumulava sobre ele, que pudessem me levar à sua apreensão, maior o distanciamento e maior o número de disfarces e máscaras sob os quais se escondia ou que eu supunha existir, minhas tentativas beiraram a contornos fugidios. Sei de Mariano o que está nas páginas de Do outro mundo. 


\begin{abstract}
This essay has as goal the study of memory in the work of Ana Maria Machado with emphasis on the tale The other world (2002), a children and youth production where the narrator, by the conversation, tries to articulate the memory of the author's lived experiences and the (re)construction, through the writing, of sensations / impressions of what was lived, updated by the person who narrates; a tale where the author and narrator are intertwined.
\end{abstract}

\title{
KEYWORDS
}

Narrator, memory, imagination, Ana Maria Machado

\section{REFERÊNCIAS}

CEIA, Carlos. Analepse. E-Dicionário de termos literários; coord. de Carlos Ceia, ISBN: 989-20-0088-9. Disponível em: $<$ http://www.edtl.com.pt/index.php?option=com_mtree\&task=viewlink\&link_id=558\&Itemid $=2>$. Acesso em: 18 abr. 2010.

FREUD, Sigmund. Escritores criativos e devaneio. In: Edição standard brasileira das obras psicológicas completas de Sigmund Freud. Rio de Janeiro: Imago, 1976. p. 147-158. v. IX, (O texto original de Freud, ao qual não tive acesso, foi proferido em 1907 e publicado em 1908.)

GIDE, André. Os moedeiros falsos. Trad. Mário Laranjeira. São Paulo: Estação Liberdade, 2009.

ISER, Wolfgang. Os atos de fingir ou o que é fictício no texto ficcional. Trad. Heidrun Krieger Olinto e Luiz Costa Lima In: COSTA LIMA, Luiz (Org.). Teoria da literatura em suas fontes. Rio de Janeiro: Civilização Brasileira, 2002. p. 955-88. cap. 3. 2.v.

ISER, Wolfgang. O fictício e o imaginário: perspectivas de uma antropologia literária. Trad. Johannes Kretschmer. Rio de Janeiro: EDUERJ, 1996.

JUNG, Carl Gustav. Os arquétipos e o inconsciente coletivo. Trad. Maria Luiza Appy et al. Petrópolis: Vozes, 2002.

MACHADO, Ana Maria. Texturas: sobre leituras e escritos. Rio de Janeiro: Nova Fronteira, 2001.

MACHADO, Ana Maria. Do outro mundo. São Paulo: Ática, 2002. (publicado também na Espanha e Inglaterra.)

PESSOA, Fernando. Disponível: <http://www.revista.agulha.nom.br/fpessoa335.html>. Acesso em: 1 jun. 2010. (Poema hortônimo, escrito por Fernando Pessoa em 2 de Outubro de 1933.)

RITA, Annabela. Mise en abyme. In: E-DICIONÁRIO DE TERMOS LITERÁRIOS. Coord. Carlos Ceia. ISBN: 989-20-0088-9, 2005. Disponível em: <http://www2.fcsh.unl.pt/edtl/verbetes/M/mise_en_abime.htm>. Acesso em: 18 fev. 2010. 
TACCA, Oscar. As vozes do romance. Trad. Margarida C. Gouveia. Coimbra-Portugal: Livraria Almedina, 1983. 